\title{
A Study Space Analysis of Interpretation Service Needs and Optimisation
}

\author{
Oghene-Ovoh Tyson Amurun ${ }^{1}$ (D)
}

Accepted: 18 October 2021

(c) Crown 2021

\begin{abstract}
The paper reports a study space analysis (SSA) of 117 published investigations of the need for interpretation services and approaches to their optimisation. The study explores literature on the adequacy and ecological validity of interpretation service and interpretation optimisation. Research on rapport building appears to be the most investigated issue. Studies on interpretation services need and planning are infrequently researched, and there exist little or no study investigating police diversity effects on interpretation service needs and the planning effects. Studies investigating cognitive load, language, and gender effects on interpreting accuracy are sparse, with most research effort concentrated in conference interpreting settings.
\end{abstract}

Keywords Interpreter-assisted interview · Police diversity $\cdot$ Joint planning and preparation $\cdot$ Language/cultural barriers · Cognitive load · Interruption · Study space analysis

\section{Introduction}

Low English proficiency (LEP) in court and traditional face-to-face investigative interviews has been linked to the incidence of coerced or false confession, wrongful conviction, injustice, and unfair treatment (Adrine 2009; Berk-Seligson 2009). The proportion of people with LEP and language service needs has increased with the changing demographic and language mix of many cities in the USA and UK (Dueñas-González et al. 1991; Jongh 2012), buttressing the need for interpretation services for victims, suspects, and witnesses to crime. Qualified interpreters have been identified as critical to ensure fairness and equal access to the justice system (Laster 1990). Ethnic mix of the justice system (Bird 1990) and nature of an investigative interview (Certoma 1990) are other determinants of interpretation needs. Within the interpreter-assisted investigative interview context, pre-interview activities (i.e. joint planning and interpreter-interviewee rapport building) and interview circumstances such as interpreter presence and interruptions have been observed to impact the investigative interview outcome. Furthermore, the need for quality interpretation

Oghene-Ovoh Tyson Amurun

1 University of Derby, One Friar Gate Square, 4-6 Agard Street, Derby DE1 1DZ, UK service with witnesses, victims, and suspects has been echoed in the recent UK Parliament review and inquiry (e.g. Justice Committee 2013). This inquiry in combination with recent research evidence has highlighted the need for policy change in interpretation service practice.

To provide a robust base for policy change, Malpass et al. (2008) noted that research must be adequate, respectable, and have overwhelming agreements. Meissner (2021) clarifies that the maturity of any field of inquiry to influence policy change is likely to be evidenced in the conduct of a review of related literature either as study space analysis (SSA), critical or narrative review (author's emphasis), systematic reviews, or meta-analyses. The investigative interview field has reached such a period in its development, having been around for over 20 years (Meissner 2021; Memon et al. 2010). Therefore, there is no gainsaying that the interpreter-assisted investigative interview subfield deserves some form of review. In the formal cognitive police investigative interview, several review efforts apply SSA and other review approaches (Meissner 2021; Memon et al. 2010; Waterhouse et al. 2020). Review efforts are also visible more than 10 years ago in interpreter-assisted interviews in medical consultation (Bauer and Alegria 2010). Purssell and McCrae opined that to "regularly review research is vital for updating evidence-based practice", and if "a review was published less than a year ago, there may be little value in conducting another review on the same treatment and outcome" 
(Purssell and McCrae 2020, p. 21). Little or no comprehensive literature reviews exists in the context of face-to-face interpreter-assisted investigative interview to map the depth and sufficiency of research. Therefore, the present paper uses the SSA technique to examine the adequacy and concentration of studies on key issues in interpretation service and other related field of research using a broad set of criteria (as highlighted in the "Methods" section). Issues addressed include motivation for interpretation service, planning, rapport building, interpreter interruption, cognitive difficulty/ load, language, and gender. In addition, the extent to which ecological validity (i.e. close resemblance of studies to real world context) is achieved by researchers is explored, focussing on the study settings, population, and instruments. It should be noted at the onset that SSA, as applied in the paper, looks not at the statistical robustness of interventions on outcomes, but on topic coverage and its relation to the associated field of practice (Malpass et al. 2008). SSA is not new to the investigative interview field. What is new is the application of SSA to explore the adequacy of existing literature within face-to-face police interpreter-assisted investigative interview.

\section{Methods}

A review of related literature is conducted with SSA of one hundred and seventeen (117) articles, books, and research reports on motivation for interpretation service, planning, rapport building, interpreter interruption, cognitive difficulty/load, language, and gender (see Table 1 for brief definition of this themes). Similarly, the data source, data collection, and coding procedure are described below.

\section{Data Collection and Sources}

Studies included in the SSA are based on an online search of five databases, namely Google Scholar, PROQUEST, PubMed, ScienceDirect, and PsycINFO, between January and May 2019. The search term for interpretation needs include "need for an interpreter" paired with "court", "police", and "interpreting". For planning and rapport building, the search terms are "rapport", "interview planning", "interview preparation" paired with "investigative interview", interpreter assisted interview", and "interpreters' presence or Interpreter". Interpreter's interruption search terms include "interruption" "interruptions effect" paired with "interview", "investigative interview", "interpreters", "communication", and "interaction". For cognitive load, the search terms are "cognitive load", "accuracy", "expertise", "performance", paired with "interpreters" and "interpreter assisted interview". Gender and cultural search terms include "gender", "language", "culture", paired with "accuracy", "performance", "quality", and "interpreters accuracy". The online search generated over four hundred and fifty $(450+)$ journal, books, reports, and grey literature.

On December 30, 2019, the above search was repeated in combination with a manual search of text as appropriate. The goal is to update the study sample and, to an extent, expand the scope of study coverage. The repeated efforts

Table 1 Theme definition and scope

\begin{tabular}{|c|c|c|}
\hline ID & Themes & Definition \\
\hline 1 & Motivation for interpretation service & $\begin{array}{l}\text { Motivation for interpretation service represents a series of explanation and rationale as to why inter- } \\
\text { pretation service is used or requested and factors influencing interpretation service provision such } \\
\text { as the need for fairness and fundamental human right, effective communication, equal access to } \\
\text { justice, migration, language mix, trust, and police diversity }\end{array}$ \\
\hline 2 & Planning and preparation & $\begin{array}{l}\text { Planning and preparation represent the first step to be taken before an investigative interview with } \\
\text { suspect, victims, and witness of criminal and non-violent crime. It covers issues such as back- } \\
\text { ground check, evidence gathering, interview goal and approach determination, and pre-interview } \\
\text { briefing (when non-English speakers is a party to the investigative interview) }\end{array}$ \\
\hline 3 & Rapport building & $\begin{array}{l}\text { Rapport building is a cognitive interview process of persuading interviewee and enhancing coopera- } \\
\text { tion so as to spur on mutual attention and voluntary disclosure of information }\end{array}$ \\
\hline 4 & Interruption & $\begin{array}{l}\text { Interruption is the use of pause or turn taking techniques by interpreters during the free recall or the } \\
\text { account phase of the PEACE model to provide accurate interpretation of source language to target } \\
\text { language and prevent information loss }\end{array}$ \\
\hline 5 & Cognitive load/difficulty & $\begin{array}{l}\text { Cognitive load refers to the volume of information available to be processed by human memory, } \\
\text { while cognitive difficulty represents the pressure on the memory as information increase in length } \\
\text { and volume }\end{array}$ \\
\hline 6 & Culture and language & $\begin{array}{l}\text { Culture are societal believes, custom, rituals, norms, and tradition that is unique to a group of people } \\
\text { with similar characteristics. Language on the other hand is the means through which culture is } \\
\text { communicated }\end{array}$ \\
\hline 7 & Gender SSA & $\begin{array}{l}\text { Gender refers to the biological and societal role of being a male and female and the impact of these } \\
\text { characteristics on ability to provide accurate and quality interpretation }\end{array}$ \\
\hline
\end{tabular}


generate an additional two hundred and ninety-six (296) studies. The paper also conducts a manual online search for specific books recommended or found through a referenced list. Overall, the efforts yield over seven hundred $(700+)$ published and unpublished studies. Irrelevant studies and research based on a scan review of the preface, abstract, or introduction sections are filtered out. The exercise reduces the SSA sample to fewer than 300 studies. From the 300 studies, the inclusion criteria that follow are used to filter studies with no link to the issues or topic of interest. The use of inclusion criteria is not new in SSA application as it has been applied previously by Memon et al. (2010, pp. 344-345) and Bartoș et al. (2014, p. 366) among others.

\section{Inclusion Criteria}

For any articles, reports, and unpublished thesis to be included or warrant exclusion:

1. It must include studies on interpreter's effects in bilingual communication in different contexts, such as police interrogation, court, asylum hearing, medical/therapeutic consultation, and conference interpreting.

2. The studies must consider motivation for interpretation service usage, planning, rapport building, interruptions effects, cognitive load or difficulty, gender, and cultural variability.

3. The studies to be included must be published or translated into English.

4. For a study where source documents are not retrievable, the abstract, preface, or introduction section must be available; otherwise, such studies are excluded.

5. It may include facts, expert opinion, and empirically tested evidence on interpreter effect in a bilingual interview.

The criteria reduce the total SSA study sample to 117 articles, books, and reports. The samples include 17 articles on the need for interpretation, 12 and 28 articles on planning and rapport building, 17 on interruptions, and 24, 5, and 14 on cognitive load, gender, and culture-language, respectively. Table 2 provide further details on the distribution of the studies included for each of the seven issues.

\section{Procedure and Coding}

The SSA looks at seven issues on motivation for and optimisation of interpretation services and investigative interview. A review of four empirical application of SSA (Bartoș et al. 2014; Cascardi and Jouriles 2018; Memon et al. 2010; Waterhouse et al. 2020) shows that the matrix design used by this studies can be grouped into two basic SSA matrix design. The first design is a single variable or diagonal SSA
Table 2 Number of studies in issues SSA

\begin{tabular}{llll}
\hline ID & Issues & Article count & \% article count \\
\hline SSA1 & $\begin{array}{c}\text { Motivation for interpreta- } \\
\text { tion service usage }\end{array}$ & 17 & 14.5 \\
SSA2 & P\&P & 12 & 10.3 \\
SSA3 & Rapport & 28 & 23.9 \\
SSA4 & Interruption & 17 & 14.5 \\
SSA5 & Cognitive load/difficulty & 24 & 20.5 \\
SSA6 & Gender & 5 & 4.3 \\
SSA7 & Culture and language & 14 & 12.0 \\
Total & & $\mathbf{1 1 7}$ & 100 \\
\hline
\end{tabular}

matrix (i.e. SV/D-SSA) design (c. f. Cascardi and Jouriles 2018), and the second a dual variables or square SSA matrix (i.e. DV/S-SSA). The SV/D-SSA differ from DV/S-SSA in that the approach does not differentiate between dependents and independent variables, instead all variable whether dependents or independents are group together on the row and also on the column to create a matrix. The paper adopts the DV/S-SSA approach, due to its simplicity and the causeeffects orientation.

For each of the seven issues, the dependent (effects) and independent (causal) variables are identified by the researcher. This means that the goal and objective of a study is regarded as dependent variable (DV) and factors influencing the goals as independent variables (IV). In addition, cross-sectional variable (CsV) relating to the study settings and methodological characteristics (e.g. instruments and analytical strategy) of each studies in the SSA is also identified. The $\mathrm{CsV}$ are derived based on the PISCA mnemonics that stands for population (P), instruments (I), settings (S), context (C), and analytical strategy (A). ${ }^{1}$ The design of the SSA matrix reported below is adapted from Waterhouse (2016) and Waterhouse et al. (2020) with little modification (see item $v$ ) to suit the purpose of the study:

(i) For the variable SSA matrix, the IV is listed across the top, against DV for each of the seven thematic issues. This implies a DV*IV matrix.

(ii) For the ecological validity matrix, the population is cross tabulated against the study settings and instruments, i.e. $\mathrm{P} * \mathrm{~S}$ and $\mathrm{P} * \mathrm{I}$ matrix for each of the thematic issues.

(iii) The first author name is then assigned to its appropriate $\mathrm{DV} * \mathrm{IV}$ (or $\mathrm{P}^{*} \mathrm{~S}$ and $\mathrm{P} * \mathrm{I}$ ) cells combination for each of the thematic issues.

\footnotetext{
$\overline{1}$ Results of the full PISCA characteristics are available from the author upon request.
} 
(iv) Frequency count of authors mentioned in a cell is entered for the corresponding cell and empty cell or zero count for cells with no mentioned authors.

(v) Author that investigate multiple $\mathrm{DV} * \mathrm{IV}$ or $\mathrm{P} * \mathrm{~S}$ or $\mathrm{P} * \mathrm{I}$ combination is repeatedly mentioned in multiple cells. As such the total mentions are greater or equal to the number of articles.

(vi) Finally, the cumulative count of authors mentioned in a row (or column) for a particular dependent (independent) variables is recorded in the total frequency column (or row) and the percentage frequency (i.e., each row proportion of the grand total mentions across the row or column) in another column (or row).

What follows is the result of the SSA using the above design and study sample in Table 1.

\section{Results}

\section{Motivation for Interpretation Service Usage SSA}

As shown in Table 3, there are eighteen (18) total mentions. This is because research by Duenas-Gonzaless et al. (1991) focusses on more than one DV*IV combination (details in Table $3 \mathrm{~b}$ in the Appendix). The result shows that more than half $(61 \%)$ of the total mentions are clustered around issues of equal access, fair trials, and fundamental human right expectation as a motivation for interpretation service usage. Less than a quarter (i.e. 22\%) explores the impact of police diversity on race relation and trust building (17\%), as well as interpretation service provision (17\%).

Interestingly, despite a handful of mentioned studies (i.e. $22 \%$ ) on impact of police diversity (Bradford et al. 2019; Edwards et al. 2006; Holdaway 1991; Miles-Johnson and Pickering 2018), no studies on police diversity and interpretation service provision cell combination is mentioned in Table 3, because interpretation service is meant to ensure fairness and equal access to justice in addition to making communication easy for non-English speakers in the judicial system and the society at large. Studies in motivation for interpretation service usage are expected to (i) involve non-English speakers and (ii) simulate real-life experience.

As shown in Table 4, many of the mentioned studies (i.e. $71 \%$ ) explore court settings, and nearly a quarter (i.e. $24 \%$ ) uses police offices. Non-English speakers as suspect, witness, and victims are investigated by $77 \%$ of the total mentions, and $18 \%$ mentions studied police recruit and officers perceptions. As a matter of methodological preference, many of the non-English speakers mentioned studies (i.e. 65\%) use material from past court proceeding and police interview in text, audio, and video format. Few studies (between 12 and $18 \%$ ) explore non-English speakers and police officers perception using interview, retrospective, and expert knowledge instruments. The sparsity of experimental and perceptual studies in the SSA implies a methodological reliance on pragmatic judgements by researchers with a possible bias issue which affects objectivity.

\section{Planning and Preparation SSA}

Planning and preparation are crucial as the first stage of the PEACE model of investigative interview. Table $5 \mathrm{~b}$ reveals 14 total mentions. The extra two mentions occur due to Hale (2011) study mentioned in three (3) DV*IV combination (see Table $5 \mathrm{~b}$ in the Appendix for details).

Table 5 reveals equal distribution of studies in the SSA across four outcomes with between 21 and $29 \%$ mentions. The outcomes are however clustered more around the effects of investigator only planning with $43 \%$ mentions. Sadly, none of this study appear to have been conducted in interpreter-assisted interview context. The lack of studies involving interpreter-assisted investigative interview in planning SSA is also buttress in Table 6. The result shows that all researches are conducted in law enforcements settings. Many of the mentioned studies (i.e. 71\%) use questionnaire and interview instruments to map perception of police officers
Table 3 Needs for interpretation service mentioned studies (frequency) matrix

\begin{tabular}{lllllll}
\hline & \multicolumn{3}{l}{ Independents variables (IV) } & & \\
\cline { 2 - 4 } & IV1 & IV2 & IV3 & IV4 & Total freq & \% Freq \\
\hline Dependents variables (IV) & & & & & & \\
Equal access, fair trials, and human right & 10 & 1 & & & $\mathbf{1 1}$ & $\mathbf{6 1 . 1}$ \\
Simplification and ease of communication & 1 & & & & $\mathbf{1}$ & $\mathbf{5 . 6}$ \\
Trust and race relation & & 3 & & & $\mathbf{3}$ & $\mathbf{1 6 . 7}$ \\
Interpretation service provision & & & 2 & 1 & $\mathbf{3}$ & $\mathbf{1 6 . 7}$ \\
Total freq & $\mathbf{1 1}$ & $\mathbf{4}$ & $\mathbf{2}$ & $\mathbf{1}$ & $\mathbf{1 8}$ & $\mathbf{1 0 0 . 0}$ \\
\% Freq & $\mathbf{6 1 . 1}$ & $\mathbf{2 2 . 2}$ & $\mathbf{1 1 . 1}$ & $\mathbf{5 . 6}$ & $\mathbf{1 0 0 . 0}$ & \\
\hline
\end{tabular}

IV1 interpretation service usage, IV2 police diversity, IV3 migration, demographics, and changing context, IV4 trust 
Table 4 Need for interpretation service ecological validity mentioned studies (frequency) matrix

\begin{tabular}{|c|c|c|c|c|c|}
\hline & \multicolumn{3}{|l|}{ Population } & \multirow[b]{2}{*}{ Total freq } & \multirow[b]{2}{*}{$\%$ Frec } \\
\hline & $\begin{array}{l}\text { Non-English } \\
\text { speakers }\end{array}$ & $\begin{array}{l}\text { General } \\
\text { public }\end{array}$ & $\begin{array}{l}\text { Police recruit and } \\
\text { protective officer }\end{array}$ & & \\
\hline \multicolumn{6}{|l|}{ Settings } \\
\hline Police & 1 & 1 & 2 & 4 & 23.5 \\
\hline Court & 11 & & 1 & 12 & 70.6 \\
\hline Generic settings (health, legal, welfare, and others) & 1 & & & 1 & 5.9 \\
\hline Total freq & 13 & 1 & 3 & 17 & 100 \\
\hline$\%$ Freq & 76.5 & 5.9 & 17.6 & 100.0 & \\
\hline \multicolumn{6}{|l|}{ Instruments } \\
\hline Face-to-face interview & 1 & & 2 & 3 & 17.6 \\
\hline Cases file, interview excerpt (text, audio, video) & 10 & & 1 & 11 & 64.7 \\
\hline Census and longitudinal national data & & 1 & & 1 & 5.9 \\
\hline News, experience, scholarly writings & 2 & & & 2 & 11.8 \\
\hline Total freq & 13 & 1 & 3 & 17 & 100.0 \\
\hline$\%$ Freq & 76.5 & 5.9 & 17.6 & 100.0 & \\
\hline
\end{tabular}

and trainers. Meanwhile, only 20\% $(n=2)$ of studies using questionnaire/interview explored interpreters perception. Half of the total mentioned studies (i.e. 50\%) explore police officers perception, and $28 \%$ (i.e. $14 \%$ each) investigate past interview material and interpreter population.

Even though ecological validity is apparent in planning and preparation SSA with the use of police officer and interpreters (own emphasis) - as argued by Clarke et al. (2011). The impact of joint planning in interpreter-assisted investigative interview settings is rarely considered. This is notwithstanding the fact that two of the studies mentioned in Table 6 (i.e. Hale 2011; Wilson and Walsh (2019) investigate interpreters' population.

\section{Rapport Building SSA}

Next to planning and preparation is the engage phase of the PEACE model which is synonymous with the concept of rapport building. Table 7 shows a total of 37 mentions. The mentions occur because 6 articles (e.g. Abbe and Brandon 2013; Bull and Soukara 2010; Goodman-Delahunty et al. 2014; Houston et al. 2017; Moraes 2013; Vallano and Compo 2011) are mentioned in multiple DV*IV combination. From the table, research efforts are concentrated on rapports skill and tactics, degree of rapport, and social persuasion by $22 \%, 14 \%$, and $14 \%$ of the total mentions. Meanwhile, the outcomes of rapport buildings are measured

Table 5 Planning and preparation mentioned studies (frequency) matrix

\begin{tabular}{|c|c|c|c|c|c|c|c|}
\hline & \multicolumn{6}{|c|}{ Independent variables (IV) } & \multirow[b]{2}{*}{$\%$ Freq } \\
\hline & $\begin{array}{l}\text { Time, belief, } \\
\text { culture, cognitive } \\
\text { closure }\end{array}$ & $\begin{array}{l}\text { Conflict of role, } \\
\text { trust, emotion }\end{array}$ & $\begin{array}{l}\text { Training, } \\
\text { supervision, and } \\
\text { Legal advisor }\end{array}$ & $\begin{array}{l}\text { Discrete or no } \\
\text { joint planning }\end{array}$ & $\begin{array}{l}\text { Interviewer and } \\
\text { interpreter skills }\end{array}$ & Total freq & \\
\hline \multicolumn{8}{|c|}{ Dependent variables (DV); } \\
\hline Planning behaviour & 1 & 1 & & & 1 & 3 & 21.4 \\
\hline $\begin{array}{l}\text { Planning frequency/ } \\
\text { volume }\end{array}$ & & & & 3 & & 3 & 21.4 \\
\hline Interview success & & & 1 & 3 & & 4 & 28.6 \\
\hline Planning performance & & 1 & & & 3 & 4 & 28.6 \\
\hline Total freq & 1 & 2 & 1 & 6 & 4 & 14 & 100.0 \\
\hline$\%$ Freq & 7.1 & 2.0 & 7.1 & 42.9 & 28.6 & 100.0 & \\
\hline
\end{tabular}


Table 6 Planning and preparation ecological validity mentioned studies (frequency) matrix

\begin{tabular}{|c|c|c|c|c|c|c|}
\hline \multicolumn{5}{|l|}{ Population } & \multirow[b]{2}{*}{ Total freq } & \\
\hline $\begin{array}{l}\text { Undergraduate } \\
\text { students }\end{array}$ & $\begin{array}{l}\text { Police } \\
\text { officers and } \\
\text { trainer }\end{array}$ & $\begin{array}{l}\text { Interview and } \\
\text { transcript }\end{array}$ & Interpreters & $\begin{array}{l}\text { Judicial } \\
\text { officers }\end{array}$ & & $\%$ Freq \\
\hline
\end{tabular}

\section{Settings}

Law enforcement

$\%$ Freq

Instruments

Questionnaire/interview

Archived transcript and video tape

Mixed: Mock \$ questionnaire

Total freq

$\%$ Freq
1 7.1

1

$\begin{array}{llll} & 7 & 1 & 2 \\ \mathbf{7 1} & \mathbf{5 0 . 0} & \mathbf{7 . 1} & \mathbf{1 4 . 3}\end{array}$

6

1

7

50.0

2

2

in terms of rapport development, perception positivity, and information accuracy by $22 \%, 16 \%$, and $10 \%$ of the total mentions.

Table 8 reports rapport building SSA ecological validity in the context of interpreter-assisted investigative interview.
It becomes apparent that, even though many of the mentioned studies (i.e. 71\%) are conducted in settings involving interpreters assistance, the perception of interpreters is rarely explored directly as only one study (i.e. Russano et al. 2014) seems to investigate this population

Table 7 Rapport building mentioned studies (frequency) matrix

\begin{tabular}{|c|c|c|c|c|c|c|c|c|c|c|c|c|c|}
\hline & \multicolumn{11}{|c|}{ Independent variable (IV) } & \multirow[b]{2}{*}{ Frequency } & \multirow[b]{2}{*}{$\%$ Frequency } \\
\hline & IV1 & IV2 & IV3 & IV4 & IV5 & IV6 & IV7 & IV8 & IV9 & IV10 & IV11 & & \\
\hline \multicolumn{14}{|c|}{ Dependent variable (DV) } \\
\hline DV1 & & 1 & 1 & & & & & & & & & 2 & 5.4 \\
\hline DV2 & & & 1 & & 1 & 1 & & & & & & 3 & 8.1 \\
\hline DV3 & 1 & & 1 & & 1 & 1 & & & & & & 4 & 10.8 \\
\hline DV4 & & 1 & 1 & & & & & & & & & 2 & 5.4 \\
\hline DV5 & & & 1 & & 1 & & & & & & & 2 & 5.4 \\
\hline DV6 & & & & 2 & & & & & & & & 2 & 5.4 \\
\hline DV7 & & & & & 2 & & 1 & & 3 & 1 & 1 & 8 & 21.6 \\
\hline DV8 & & & 1 & & & & & & & & & 1 & 2.7 \\
\hline DV9 & & & & & & & 1 & & & & & 1 & 2.7 \\
\hline DV10 & & & 1 & 1 & & & & & & & & 2 & 5.4 \\
\hline DV11 & & & 1 & 2 & & & 1 & & 1 & & 1 & 6 & 16.2 \\
\hline DV12 & & & & & & & & 1 & 2 & & & 3 & 8.1 \\
\hline DV13 & & & & & & & & 1 & & & & 1 & 2.7 \\
\hline Total freq & 1 & 2 & 8 & 5 & 5 & 2 & 3 & 2 & 6 & 1 & 2 & 37 & 100 \\
\hline$\%$ Freq & 2.7 & 2.0 & 21.6 & 13.5 & 13.5 & 5.4 & 8.1 & 5.4 & 16.2 & 2.7 & 5.4 & 100.0 & \\
\hline
\end{tabular}

IV Key:

IV1 coordination, mutual attention, positivity, IV2 motivational and interpersonal interview, IV3 rapport skills and tactics: verbal/non-verbal, IV4 rapport continuum: low or high, initial, or absent, IV5 social persuasion/rapport, IV6 coercive vs social persuasion, IV7 rapport determinants or factor, IV8 assessment feedback, IV9 bilingual and/or monolingual discourse, IV10 sitting position, IV11 pre-interview interpretertarget rapport building

DV Key:

DV1 resistance/CIT, DV2 responsiveness, rapid disclosure, and cooperation, DV3 relevant/accurate information (IRI), DV4 information volume, DV5 confession level, DV6 recall accuracy and anxiety, DV7 rapport building/development, DV8 post-event misinformation susceptibility, DV9 justice perception and self-promotion, DV10 interview quality, outcome, dynamics, DV11 positive evaluation/perception of interview, DV12 small talks/eye contact/non-verbal emotional cue, DV13 diagnostic Issues 
Table 8 Rapport building SSA ecological validity mentioned studies (frequency) matrix

\begin{tabular}{|c|c|c|c|c|c|c|c|c|c|c|c|c|c|}
\hline & \multicolumn{10}{|c|}{ Population (pop) } & \multirow[b]{2}{*}{ P11 } & \multirow[b]{2}{*}{ Total Freq } & \multirow[b]{2}{*}{$\begin{array}{l}\% \\
\text { Freq }\end{array}$} \\
\hline & P1 & $\mathbf{P 2}$ & P3 & $\mathbf{P 4}$ & P5 & P6 & P7 & P8 & P9 & P10 & & & \\
\hline \multicolumn{14}{|l|}{ A. Settings: } \\
\hline Law enforcement & 4 & 4 & 1 & 3 & 3 & 6 & & & 1 & & 1 & 23 & 71.9 \\
\hline Medical Settings & 1 & 1 & & & & & & & & 4 & & 6 & 18.8 \\
\hline Forensic & 1 & & & & & & & 1 & & & & 2 & 6.3 \\
\hline Business enterprise & & & & & & & 1 & & & & & 1 & 3.1 \\
\hline Total freq & 6 & 5 & 1 & 3 & 3 & 6 & 1 & 1 & 1 & 4 & 1 & 32 & 100.0 \\
\hline$\%$ Freq & 18.8 & 15.6 & 3.1 & 9.4 & 9.4 & 18.8 & 3.1 & 3.1 & 3.1 & 12.5 & 3.1 & 100.0 & \\
\hline \multicolumn{14}{|l|}{ B. Instruments } \\
\hline Questionnaire/interview/narrative & 5 & 5 & 1 & & 1 & 1 & 1 & 1 & & & 1 & 16 & 48.5 \\
\hline Desk research & & & & & & & & & 1 & 3 & & 4 & 12.1 \\
\hline Archived transcript-video tape & 1 & & & 3 & & 4 & & & & & & 8 & 24.2 \\
\hline Self-recorded audio/video interview & & & & & 1 & 1 & & & & 1 & & 3 & 9.1 \\
\hline Mock video & & & & & & 1 & & & & & & 1 & 3.0 \\
\hline Computer simulation & & & & & 1 & & & & & & & 1 & 3.0 \\
\hline Total freq & 6 & 5 & 1 & 3 & 3 & 7 & 1 & 1 & 1 & 4 & 1 & 33 & 100.0 \\
\hline$\%$ Freq & 18.2 & 15.2 & 3.0 & 9.1 & 9.1 & 21.2 & 3.0 & 3.0 & 3.0 & 12.1 & 3.0 & 100.0 & \\
\hline
\end{tabular}

P1 undergraduate, P2 police investigators, P3 terrorist, P4 investigation transcript, P5 volunteer, P6 audio-video tape, P7 applicants, P8 children victim, $\mathrm{P} 9$ journals, books, gazette, bulletin, and reports, P10 physician and patients, P11 interpreters

Table 8 shows that $21 \%$ of the mentioned studies in rapport building SSA appears to subjectively deduce interpreters perception from interview material in text, video, and audio format, while only one study uses questionnaire and interview instruments. The second most investigated populations are the undergraduate students, police investigators, medical physician, and patients by $18.2 \%, 15 \%$, and $12 \%$ of the total mentioned studies, respectively. The low exploration of interpreters and police investigators' population signposts a less than desirable level of ecological validity.

\section{Interpreter's Interruption SSA}

Notwithstanding the SSA of rapport building researches, Tables 9 and 10 explore yet another important issues in the third phase of the PEACE model, i.e. the account phase. This issue is associated with the impact of interpreters' interruption during the free-recall segments of investigative interview. Table 9 reports on the adequacy of research in interruption SSA and includes a total of 18 mentions.

The result of Table 9 shows task resumption, free recall initiation, and information retrieval as the most explored interruption outcomes by $22 \%, 11 \%$, and $11 \%$ of the total mentioned studies, respectively. Meanwhile, demographic variable such as gender, age and status, segmentation, or turn appear as the most investigated variables manipulated by $17 \%$ of the mentioned studies.

Interestingly as demonstrated in Table 10, many of mentioned interruption researches are distributed across; law enforcement, academic, mental health, and business organisational settings by $33 \%$ and $26 \%$ (i.e. $12.5 \%+12.5 \%$ ) for law enforcement and mental health, respectively, and $13 \%$ each for academic and business settings. In all of this, undergraduate bilingual students, interpreters, and judicial officers-interviewee population are used most by $32 \%, 26 \%$, and $17 \%$ of the total mentions in Table 10. Rather than using questionnaire and interview method for perceptual mapping, past interview material (text, audio, video), simulation program, and self-recorded mock audio-visual conversation are instruments of choice by $34 \%, 30 \%$, and $20 \%$ of the total mentioned studies in Table 10. This implies that real-life interpreter-assisted interview study via observation and perceptual construction is inarguably missing in interruption SSA, signposting possible internal and ecological validity issues.

\section{Cognitive Difficulty SSA}

Furthermore, because interpreting accuracy is important to strengthen and validate interviewee evidential statements presented to the court, the result of Tables 11 and 12 explores the adequacy of research on the impact of 
Table 9 Interruption mentioned studies (frequency) matrix

\begin{tabular}{|c|c|c|c|c|c|c|c|c|c|c|}
\hline & \multicolumn{8}{|c|}{ Independents variables (IV) } & \multirow[b]{2}{*}{ Total freq } & \multirow[b]{2}{*}{$\%$ Freq } \\
\hline & IV1 & IV2 & IV3 & IV4 & IV5 & IV6 & IV7 & IV8 & & \\
\hline \multicolumn{11}{|l|}{ Dependent variables (DV) } \\
\hline Interruption frequency, type, and resistance & 2 & & & & & 1 & & & 3 & 16.7 \\
\hline Free recall initiation, maintenance, and redition & & 1 & 1 & & & & & & 2 & 11.1 \\
\hline Attitude and engagement & & 1 & & & & & & & 1 & 5.6 \\
\hline Interruption usage & & & & 1 & & & & & 1 & 5.6 \\
\hline Cross-cultural occurrence and frequency & & 1 & & & & & & & 1 & 5.6 \\
\hline Retrieval cue/recall & & 2 & & & & & & & 2 & 11.1 \\
\hline Task time and resumption or recovery & 1 & 1 & & & 1 & & & 1 & 4 & 22.2 \\
\hline Power/dominance perception & & 1 & & & & & & & 1 & 5.6 \\
\hline Miscommunication & & & 1 & & & & & & 1 & 5.6 \\
\hline Interpreting accuracy & & & 1 & & & & & & 1 & 5.6 \\
\hline Error likelihoods & & & & & & & 1 & & 1 & 5.6 \\
\hline Total freq & 3 & 7 & 3 & 1 & 1 & 1 & 1 & 1 & 18 & 100.0 \\
\hline$\%$ Freq & 16.7 & 7.0 & 16.7 & 5.6 & 5.6 & 5.6 & 5.6 & 5.6 & 100.0 & \\
\hline
\end{tabular}

IV1 demographic, i.e. gender, status, and age, IV2 interrupting behaviour, IV3 discuss segmentation/turn taking, IV4 socio-culture, IV5 goal encoding-rehearsal, IV6 interpreter status: trained vs. ad hoc/untrained, IV7 recall memory capacity, IV8 contextual cue and preparation

cognitive load, which creates cognitive difficulty on interpretation service accuracy. Table 11 reveals $(35$ total mentions. The result shows that interpretation training type, i.e. simultaneous versus consecutive interpreting, interpreting experience level (non, short, and long), and the proficiency status (i.e. expert versus novice), appears as the most studied

Table 10 Interruption SSA ecological validity mentioned studies (frequency) matrix

\begin{tabular}{|c|c|c|c|c|c|c|c|c|c|c|c|c|}
\hline & \multicolumn{10}{|c|}{ Population (P) } & \multirow[b]{2}{*}{ Total freq } & \multirow[b]{2}{*}{$\%$ Freq } \\
\hline & $\mathbf{P 1}$ & $\mathbf{P 2}$ & $\mathbf{P 3}$ & $\mathbf{P 4}$ & P5 & P6 & P7 & P8 & P9 & P10 & & \\
\hline \multicolumn{13}{|l|}{ Settings } \\
\hline Law enforcement & & & & & & & 4 & & & 4 & 8 & 33.3 \\
\hline Journalism/discuss & & & 1 & & & & & & & & 1 & 4.2 \\
\hline Artificial intelligence & & & & 1 & & & & & & & 1 & 4.2 \\
\hline Teaching/academic & 1 & 1 & 1 & & & & & & & & 3 & 12.5 \\
\hline Behavioural/cognitive & & & 2 & & & & & 1 & & & 3 & 12.5 \\
\hline Medical/clinical health & & & & 1 & & & & & 1 & 1 & 3 & 12.5 \\
\hline Workplace task performance & & & 2 & & & 1 & & & & & 3 & 12.5 \\
\hline Multidisciplinary & & & & & 1 & & & & & & 1 & 4.2 \\
\hline Automobile & & & 1 & & & & & & & & 1 & 4.2 \\
\hline Total freq & 1 & 1 & 7 & 2 & 1 & 1 & 4 & 1 & 1 & 5 & 24 & 100.0 \\
\hline$\%$ Freq & 4.2 & 4.2 & 29.2 & 8.3 & 4.2 & 4.2 & 16.7 & 4.2 & 4.2 & 20.8 & 100.0 & \\
\hline \multicolumn{13}{|l|}{ Instruments } \\
\hline Desk research & & & & & 1 & & & & & & 1.0 & 4.3 \\
\hline Transcript/excerpt/interview video tape & & & & & & & 4 & & & 4 & 8.0 & 34.8 \\
\hline Self-recorded audio/video conversation & 1 & 1 & 2 & 1 & & & & & 1 & 1 & 7.0 & 30.4 \\
\hline Simulating programme & & & 3 & & & 1 & & 1 & & & 5.0 & 21.7 \\
\hline Online discuss platform & & & & 1 & & & & & & & 1.0 & 4.3 \\
\hline Pen and paper recording & & & 1 & & & & & & & & 1.0 & 4.3 \\
\hline Total freq & 1 & 1 & 6 & 2 & 1 & 1 & 4 & 1 & 1 & 5 & 23 & 100 \\
\hline$\%$ Freq & 4.3 & 4.3 & 26.1 & 8.7 & 4.3 & 4.3 & 17.4 & 4.3 & 4.3 & 21.7 & 100.0 & \\
\hline
\end{tabular}

P1 postgraduate bilingual/monolinguals, P2 learners of English, P3 undergraduate student (paid/unpaid), P4 volunteer, P5 published studies, P6 employees, P7 judicial officer and interviewee, P8 expert/subject panel (paid or unpaid), P9 physician and patient, P10 interpreters 


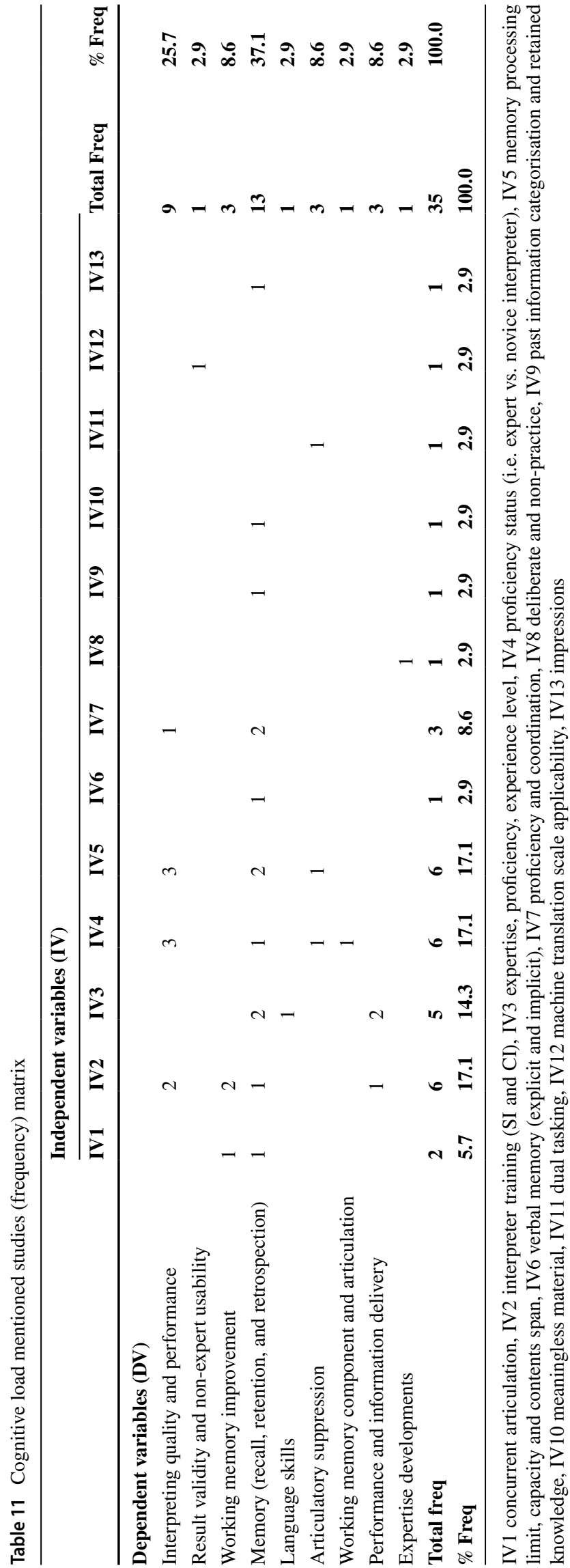

intervention by $17 \%$ of the total mentions. The intervention are mostly studied in relation to their roles on remembering, retention, and recall capacity of the memory by $37 \%$ of the total mentions and interpreting quality and performance by $25 \%$ of the total mentions.

In Table 12, result reveals that many of the studies investigating the impact of cognitive span on interpretation performance and quality are concentrated in conference interpreting with over $56 \%$ of the total mentions. Linguistic and cognitive psychology settings are the second with $22 \%$ and $14 \%$ of the total mentions, and none of the studies occurred in interpreter-assisted investigative interview. The result shows that substantial proportion of mentioned studies (i.e. about 67\%) explores the perception of interpreting students (25\%), untrained bilinguals (17\%), and expert interpreters $(25 \%)$. Of course the use of controlled experiments with the fMRI scan experiments by $2 \%$ of the total mentions is also visible in Table 12a, except that such study is demonstrated in a medical laboratory. More so, other mentioned studies using recorded audio and video tape (33\%), pen and paper (17\%), questionnaire/ interview (13\%), and auditory sound and visual display (i.e. 20\%) were all outside the domain of interpreterassisted investigative interview.

\section{Cultural Difference SSA}

Beside exploring adequacy of research on cognitive difficulty, the result in Table 13 and 14, analyse the adequacy of researches on the impact of language and cultural impact on interpretation accuracy. Table 15 shows a total of 15 mentions (details in Table 13b in the Appendix).

Apparently, with the exception of studies investigating the impact of cultural alertness and disclosure with 53\% mentions, there exist less than desirable attention on other independent variables in Table 13. Meanwhile, only accuracy and completeness with $27 \%$ mentions and sociolinguistic or pragmalinguistic failure with $13 \%$ mentions are the most explored outcomes in Table 13.

Furthermore, the result of Table 14 shows a quarter (or close to a quarter) of the mentioned studies as exploring the perception of interpreting students (20\%) and published materials (25\%) objective information. The good news however is that these studies are concentrated in court interpreting settings with 39\% mentions. Meanwhile, desk research, questionnaire or interview method, and written test (i.e., pen and paper) are the most used instruments by $35 \%, 20 \%$, and $15 \%$ of the mentions studies. No field study or experiment is observed except for the use of automated observatory devise by only one study or 5\% of the total mentions. Interestingly none of this study is conducted in interpreter-assisted investigative interview context. 


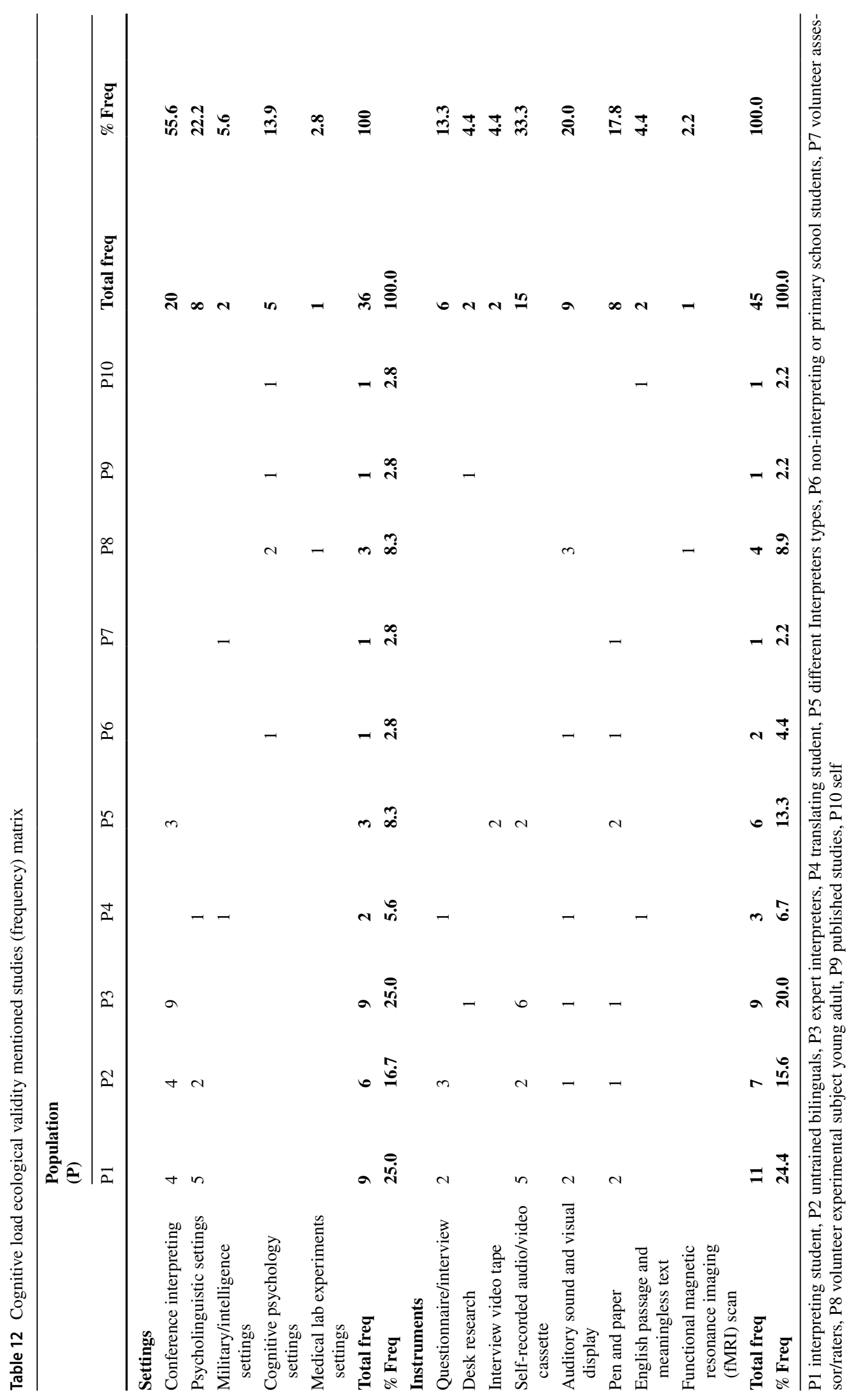


Table 13 Language/cultural effect mentioned studies (frequency) matrix

\begin{tabular}{|c|c|c|c|c|c|c|c|c|}
\hline & \multicolumn{6}{|c|}{ Independent variables (IV) } & \multirow[b]{2}{*}{ Total freq } & \multirow[b]{2}{*}{$\%$ Freq } \\
\hline & IV1 & IV2 & IV3 & IV4 & IV5 & IV6 & & \\
\hline \multicolumn{9}{|l|}{ Dependent variable (DV) } \\
\hline Accuracy and completeness & 1 & & & 2 & 1 & & 4 & 26.7 \\
\hline Interception, distortion, and communication breakdown & & & & 1 & & & 1 & 6.7 \\
\hline Usage frequency & & & 1 & & & & 1 & 6.7 \\
\hline Cross-cultural difference reduction & & 1 & & & & & 1 & 6.7 \\
\hline Interpreting flow & & & & 1 & & & 1 & 6.7 \\
\hline Role perception & & & & 1 & & & 1 & 6.7 \\
\hline Pragmalinguistic and sociolinguistic failure & & & & 2 & & & 2 & 13.3 \\
\hline Fair justice & & & & 1 & & & 1 & 6.7 \\
\hline Memory and remembering & & & 1 & & & & 1 & 6.7 \\
\hline Articulatory suppression & & & & & & 1 & 1 & 6.7 \\
\hline Pupils dilation & & & & & 1 & & 1 & 6.7 \\
\hline Total freq & 1 & 1 & 2 & 8 & 2 & 1 & 15 & 100 \\
\hline$\%$ Freq & 6.7 & 6.7 & 13.3 & 53.3 & 13.3 & 6.7 & 100.0 & \\
\hline
\end{tabular}

IV1 Lingual-cultural proficiency, IV2 cultural interpretation, IV3 language verb modality and varieties, IV4 cultural alertness, disclosure, and filtering, IV5 language familiarities, complexity, and similarities, IV6 word knowledge

\section{Gender Difference SSA}

Finally, the adequacy of researches on gender in translation and interpretation studies is explored and reported in Tables 15 and 16 (details in Table 15b in the Appendix). Table 15 shows 5 total mentions. Except for studies investigating gender difference in interaction success with $40 \%$ and $60 \%$ mentions, other outcomes or intervention variables in Table 15 have a study each.

Similarly, Table 16 shows that researches on gender are sparsely conducted in business, cognitive psychology and
Table 14 Language/cultural effect SSA ecological validity mentioned studies (frequency) matrix

\begin{tabular}{|c|c|c|c|c|c|c|c|c|c|c|}
\hline & \multicolumn{7}{|c|}{ Population } & \multirow[b]{2}{*}{ P8 } & \multirow[b]{2}{*}{ Total freq } & \multirow[b]{2}{*}{$\%$ Freq } \\
\hline & P1 & $\mathrm{P} 2$ & P3 & P4 & P5 & P6 & P7 & & & \\
\hline \multicolumn{11}{|l|}{ Settings } \\
\hline Courts interpreting & & 1 & 1 & & 3 & 2 & & & 7 & 38.9 \\
\hline Linguistic/academic & & 1 & & & 2 & & & & 3 & 16.7 \\
\hline Conference interpreting & 1 & & 1 & & & & 1 & & 3 & 16.7 \\
\hline Medical/clinical health & 1 & & & 1 & & & & & 2 & 11.1 \\
\hline Community interpreting & & & 1 & & & & & & 1 & 5.6 \\
\hline Military establishments & & & & & & & & 1 & 1 & 5.6 \\
\hline Automotive settings & 1 & & & & & & & & 1 & 5.6 \\
\hline Total freq & 3 & 2 & 3 & 1 & 5 & 2 & 1 & 1 & 18 & 100.0 \\
\hline$\%$ Freq & 16.7 & 11.1 & 16.7 & 5.6 & 27.8 & 11.1 & 5.6 & 5.6 & 100.0 & \\
\hline \multicolumn{11}{|l|}{ Instruments } \\
\hline Questionnaire/interview & 2 & & 1 & & & & 1 & & 4 & 20 \\
\hline Focus group & & & & 1 & & & & & 1 & 5 \\
\hline Desk research & & 1 & & & 5 & 1 & & & 7 & 35 \\
\hline $\begin{array}{l}\text { Archived interview text, audio and } \\
\text { video tape }\end{array}$ & & 1 & & & & 1 & & & 2 & 10 \\
\hline Pen and paper & 1 & 1 & & & & & & 1 & 3 & 15 \\
\hline Video expert & 1 & & & & & & & & 1 & 5 \\
\hline English passage text & & & & & & & & 1 & 1 & 5 \\
\hline Automated observatory device & & & 1 & & & & & & 1 & 5 \\
\hline Total freq & 4 & 3 & 2 & 1 & 5 & 2 & 1 & 2 & 20 & 100.0 \\
\hline$\%$ Freq & 20.0 & 15.0 & 10.0 & 5.0 & 25.0 & 10.0 & 5.0 & 10.0 & 100.0 & \\
\hline
\end{tabular}

P1 interpreting student, P2 poet/prose, popular saying, and business text, P3 expert interpreters, P4 medical professionals, P5 published and unpublished materials, P6 interview textual extract, audio and video records, P7 end users, P8 translating student and volunteer 
Table 15 Gender effect mentioned studies (frequency) matrix

\begin{tabular}{llllll}
\hline & \multicolumn{2}{l}{$\begin{array}{l}\text { Independent } \\
\text { variable (IV) }\end{array}$} & & \\
\cline { 2 - 4 } M, & IV1 & IV2 & IV3 & Total freq & \% Freq \\
\hline Dependent variable (DV) & & & & & \\
Interaction success & & 2 & & 2 & 40 \\
Managerial success & 1 & & & 1 & 20 \\
Cognitive abilities & & 1 & & 1 & 20 \\
Use of language preference & & & 1 & 1 & 20 \\
Total freq & 1 & 3 & 1 & 5 & 100 \\
\% Freq & 20 & 60 & 20 & 100 & \\
\hline
\end{tabular}

IV1 gender-based interpretation style, IV2 gender difference, IV3 translators gender

translation settings with $25 \%, 12.5 \%$, and $12.5 \%$ mentions, respectively. Meanwhile, most of the research seem to have originated from medical setting with $50 \%$ mentions. Surprisingly, many of the researches mentioned (i.e. 33\%) use direct observation of sign language interpreters, supervisors or line manager, and college students, while untrained bilinguals and medical interview material are the most studied populations with $22 \%$ mention each.

\section{Discussion}

This paper explores the adequacy of researches on six issues affecting investigative interview and interpretation service optimization. The paper additionally explores the adequacy of researches on motivation for interpretation service usage in investigative interview and the society at large. The goal of the SSA is to gauge the adequacy and validity of researches on each of the seven issues in interpreted-assisted investigative interview context. It becomes apparent from the SSA of research on motivation for interpretation service usage that researches explored the role of users and societal expectation as a motivation for interpretation service usage more than any other motivation, e.g. migration and police diversity. Undoubtedly, researches on expectation are useful for fostering fairness, equal access, and effective communication. The need for manpower planning and managements by ministry of justice (MOJ) to meet the increasing interpretation service demand justified the need for more researches into other motivating factors that are likely to encourage increased interpretation service usage. Such research endeavour is useful for providing empirical as well as theoretical basis for policy change.

Furthermore, the SSA observed that researches on planning phase of the PEACE model focusses on nature and impact of planning - by investigators, on investigative interview optimization. None of the studies mentioned in planning SSA explores the nature and impact of joint interpreterinvestigators planning, on investigative interview goal. This suggest that even though policy makers are aware of the consequence of planning and preparation to investigative interview goals (c.f. Kim et al. 2018; Walsh and Bull 2010). Their knowledge is domain specific as there is not enough evidence on the impact of pre-interview planning and preparation-by investigators and interpreters, or lack of it, on
Table 16 Gender effect SSA ecological validity mentioned studies (frequency) matrix

\begin{tabular}{|c|c|c|c|c|c|c|c|c|c|}
\hline & \multicolumn{7}{|c|}{ Population (P) } & \multirow[b]{2}{*}{ Total freq } & \multirow[b]{2}{*}{$\%$ Freq } \\
\hline & P1 & $\mathbf{P 2}$ & $\mathbf{P 3}$ & P4 & P5 & P6 & P7 & & \\
\hline \multicolumn{10}{|l|}{ Settings } \\
\hline Medical and health service & 1 & & 2 & 1 & & & & 4 & 50 \\
\hline Production or business & & 1 & & & 1 & & & 2 & 25 \\
\hline Cognitive psychology & & & & & & 1 & & 1 & 12.5 \\
\hline Language study and translation & & & & & & & 1 & 1 & 12.5 \\
\hline Total freq & 1 & 1 & 2 & 1 & 1 & 1 & 1 & 8 & 100 \\
\hline$\%$ Freq & 12.5 & 12.5 & 25.0 & 12.5 & 12.5 & 12.5 & 12.5 & 100.0 & \\
\hline \multicolumn{10}{|l|}{ Instruments } \\
\hline Books passage & & & & & & & 1 & 1 & 11.1 \\
\hline Questionnaire/interview & 1 & & & & & & & 1 & 11.1 \\
\hline Focus group & 1 & & & & & & & 1 & 11.1 \\
\hline Desk research & & & 1 & 1 & & & & 2 & 22.2 \\
\hline $\begin{array}{l}\text { Interview textual transcript, } \\
\text { audio and video tape }\end{array}$ & & & 1 & & & & & 1 & 11.1 \\
\hline Direct observation & & 1 & & & 1 & 1 & & 3 & 33.3 \\
\hline Total freq & 2 & 1 & 2 & 1 & 1 & 1 & 1 & 9 & 100.0 \\
\hline$\%$ Freq & 22.2 & 11.1 & 22.2 & 11.1 & 11.1 & 11.1 & 11.1 & 100.0 & \\
\hline
\end{tabular}

P1 untrained bilinguals, P2 sight interpreters, P3 medical interview material, P4 family member, P5 supervisor/manager, P6 college students, P7 professional translators 
investigative interview outcomes. As such more research is needed to unravel the black box of planning.

By contrast, SSA of the engage phase of the PEACE model, i.e. rapport building, shows a well-researched investigative interview domain. More so, rapport building researches benefit from multi-disciplinary research efforts in medical and police interview. Notwithstanding the research developments in rapport building strand of literature, the paper observed validity issues with studies in the rapport building SSA. The issues occurs because, rarely, except for a study by Russano et al. (2014), there was a study with specific focus on interpreters' population. The need to explore the perception of interpreters vis-àvis investigators is demonstrated in a study by Houston et al. (2017) where it was observed that pre-interview rapport building between interpreters and interview impacted the subsequent interview positively. The existing PEACE model however does not imply the role of interpreters to be that of rapport building. As such it remains to be known from interpreters-investigators perspective whether interpreters should be involve in rapport building and when exactly is it safe to do so. Moreover, for the interruption SSA, researches focus on examining interruption effect via a thematic content analysis of archived interview materials and self-recorded videos. Real-time evaluation of interruption effects during an interview session or exploration of interpreters-investigators experience via the use of interview, focus group, and questionnaire were not a commonplace in the SSA. The sparsity of real interview study of interruption effect shows that existing evidence on interruption effects are at best an objective extrapolation based on past event with no context specific evidence serving as a basis for policy change in interpreter-assisted interview.

On a final note, researches on language, gender, and cognitive load impact show few experimental studies that are conducted in translation, conference interpreting, and cognitive psychology settings. There exist little or no research on factors affecting interpretation service in the context of interpreterassisted investigative interview despite the justice system need for quality interpretation. Lack of studies on factors affecting interpretation service implies that policy-makers, institutions, and practitioners in the field of interpretation services have no empirical base for advocating for a policy change in interpretation service practice as well as propose possible solution on how to curb interpretation service quality and accuracy issues.

\section{Conclusion}

The paper evaluates the adequacy of conceptual as well as empirical studies on motivation for interpretation service usage, investigative interview, and interpretation service optimisation. The intent is to map the quadrant of much, mild, and little attention and use the findings to guide future investigation. It is observed that in rapport building, interruption effects are the most explored issues, while motivation for interpretation service usage, planning, cognitive difficulty, and language is mildly researched. Researches on gender effects appear the least studied area with only a handful of empirical exploration. Meanwhile, despite the much, mild, and little researches, across all issues analysed in this study, the perception of interpreters who are essential in the study of interpreter-assisted interview issues is rarely directly sought. This is notwithstanding the use of secondary material explored via interpretivism and pneumatic The rareness of interpreters' perception possess a doubt on the validity and context dependency of evidence currently used in the field of face-to-face interpreter-assisted investigative interview. Therefore, it is apparent that more innovative research and replicability of existing findings be conducted to provide a respectable base for policy change.

\section{Limitation and Future Direction}

Even though the search methodology is carefully planned, the SSA study does not claim to conduct an exhaustive review of all literature. Many published and unpublished reports, drafts, and books with restricted access are not included in the review. In addition, the SSA approach taken in this paper involves DV/S matrix approach, which, even though helps avoid cumbersomeness of SV/D matrix approach, imposes application difficulty when applied to single variable studies. The SSA studies however succeeded in providing a base and aggregated pool of literature for more rigorous review in the future. Future SSA within the context of interpreter-assisted investigative interview will benefit from exploring a wider range of studies beyond what is done in this paper using SSA matrix approach of choice.

Supplementary Information The online version contains supplementary material available at https://doi.org/10.1007/s11896-021-09485-4.

\section{Declarations}

Ethical Approval This article does not contain any studies with human participants or animals performed by any of the authors.

Informed Consent Not applicable for this article as it does not contain any image, picture, case study, report, participant, or individual.

Conflict of Interest The author declares no competing interests. 
Open Access This article is licensed under a Creative Commons Attribution 4.0 International License, which permits use, sharing, adaptation, distribution and reproduction in any medium or format, as long as you give appropriate credit to the original author(s) and the source, provide a link to the Creative Commons licence, and indicate if changes were made. The images or other third party material in this article are included in the article's Creative Commons licence, unless indicated otherwise in a credit line to the material. If material is not included in the article's Creative Commons licence and your intended use is not permitted by statutory regulation or exceeds the permitted use, you will need to obtain permission directly from the copyright holder. To view a copy of this licence, visit http://creativecommons.org/licenses/by/4.0/.

\section{References}

Abbe A, Brandon SE (2013) The role of rapport in investigative interviewing: A review. Journal of Investigative Psychology and Offender Profiling 10:237-249. https://doi.org/10.1002/jip.1386

Adrine HRB (2009) Fundamental fairness and limited english proficiency: One should not prevent the other. Proteus 18(3):1-5

Bartoș SE, Berger I, Hegarty P (2014) Interventions to reduce sexual prejudice: a study-space analysis and meta-analytic review. J Sex Res 51(4):363-382. https://doi.org/10.1080/00224499.2013. 871625

Bauer AM, Alegria M (2010) Impact of patient language proficiency and interpreter service use on the quality of psychiatric care: a systematic review. Psychiatr Serv 61(8):765-773. https://doi.org/ $10.1176 /$ ps.2010.61.8.765

Berk-Seligson S (2009) Coerced Confessions. Language, Power and Social Process: Vol. 25 [HC]. Mouton De Gruyter

Bird G (1990) International Law, Natural Justice and Language Rights in Australia. Second International Conference on Lan-guage and Law, Hong Kong, China

Bradford B, Topping J, Martin R, Jackson J (2019) Can diversity promote trust? Neighbourhood context and trust in the police in northern Ireland. Polic Soc 29(9):1022-1041. https://doi.org/10. 1080/10439463.2018.1479409

Bull R, Soukara S (2010) Four studies of what really happens in police interviews. In: Lassiter GD, Meissner CA (eds) Police interrogations and false confessions: current research, practice, and policy recommendations. APA 81-95

Cascardi M, Jouriles EN (2018) A study space analysis and narrative review of trauma-informed mediators of dating violence. Trauma Violence and Abuse (Tva), 19(3). Article 266-285:1-20. https:// doi.org/10.1177/1524838016659485

Certoma GL (1990) Law in a Multicultural Society: The Australian Case. Federation of Ethnic Communities Councils. One-day Conference on Multiculturalism and the Law, Sydney, Australia

Clarke C, Milne RJ, Bull R (2011) Interviewing suspects of crime: the impact of peace training, supervision and the presence of a legal advisor. J Investig Psychol Offender Profiling 8:149-162. https:// doi.org/10.1002/jip.144

Dueñas-González R, Vásquez VF, Mikkelson H (1991) Fundamentals of court interpretation: Theory, policy, and practice. Durham, NC: Carolina Academic Press

Edwards R, Alexander C, Temple B (2006) Interpreting trust: abstract and personal trust for people who need interpreters to access services. Sociological Research Online 11(1):1-13. https://doi.org/ 10.5153/sro. 1077

Goodman-Delahunty J, Martschuk N, Dhami MK (2014) Interviewing high value detainees: securing cooperation and disclosures. Appl Cogn Psychol 28:883-897. https://doi.org/10.1002/acp.3087
Hale S (2011) Interpreter Policies, Practices and Protocols in Australian Courts and Tribunals; A National Survey. Australasian Institute of Judicial Administration. www.aija.org.au; www.mmpmelb.com.au

Holdaway S (1991) Recruting a Multi-Racial Police Force. TSO Press

Houston KA, Russano MB, Ricks EP (2017) Any friend of yours is a friend of mine: investigating the utilization of an interpreter in an investigative interview. Psychology, Crime and Law 23(4):413426. https://doi.org/10.1080/1068316X.2017.1290091

Jongh EM de (2012) From the classroom to the courtroom: A guide to interpreting in the U.S. justice system. American Translators Association Scholarly Monograph Series (ATA): Vol. 17 [ebook]. John Benjamins

Justice Committee (2013) The Budget and Structure of the Ministry of Justice (HC 97-II). London, UK. Home of Common: Justice Committee

Kim J, Walsh D, Bull R, Bergstrøm H (2018) Planning ahead? An exploratory study of South Korean investigators beliefs about their planning for investigative interviews of suspects. J Police Crim Psychol 33:158-174. https://doi.org/10.1007/s11896-017-9243-z

Laster K (1990) Legal interpreters: conduits to social justice? J Intercult Stud 11(2):15-32. https://doi.org/10.1080/07256868.1990. 9963364

Malpass RS, Tredoux CG, Compo NS, Mc-Quiston-Surrett D, Maclin OH, Zimmerman LA, Topp LD (2008) Study space analysis for policy development. Appl Cogn Psychol 22(6) Article 10990720:789801. https://doi.org/10.1002/acp.1483

Meissner CA (2021) What works systematic reviews and meta-analyses of the investigative interviewing research literature - meissner - applied cognitive psychology - wiley online library. Appl Cogn Psychol 35(2) Article 3808. https://doi.org/10.1002/acp.3808

Memon A, Meissner CA, Fraser J (2010) The cognitive interview: a metaanalytic review and study space analysis of the past 25 years. Psychol Public Policy Law 16(4):340-372. https://doi.org/10.1037/a0020518

Miles-Johnson T, Pickering S (2018) Police recruits and perceptions of trust in diverse groups. Police Pract Res 19(4):311-328. https:// doi.org/10.1080/15614263.2017.1364162

Moraes SL (2013) The positive relationship between police rapport tactics and investigative interviewing outcomes $[\mathrm{Ph}$. D. Clinical Psychology]. Fielding Graduate University

Purssell E, McCrae N (2020) How to perform a systematic literature review: A guide for healthcare researchers, practitioners and students. Cham, Switzerland: Springer

Russano MB, Narchet FM, Kleinman SM (2014) Analysts, interpreters, and intelligence interrogations: perceptions and insights. Appl Cogn Psychol 28:829-846. https://doi.org/10.1002/acp.3070

Vallano JP, Compo NS (2011) A comfortable witness is a good witness: rapport-building and susceptibility to misinformation in an investigative mock-crime interview. Appl Cogn Psychol 25:960-970. https://doi.org/10.1002/acp.1789

Walsh D, Bull R (2010) What really is effective in interviews with suspects? A study comparing interviewing skills against interviewing outcomes. Leg Criminol Psychol 15:305-321. https://doi.org/10. $1348 / 135532509 x 463356$

Waterhouse GF (2016) Investigating the forensic interviewing of children: Multiple interviews and social Support. Ph. D. London South Bank University, London, UK

Waterhouse GF, Ridley AM, Bull R, Wilcock R (2020) A study space analysis for multiple interviewing of child witnesses. Child Abuse Review. Wiley Online Library. https://doi.org/10.1002/car.2604

Wilson L, Walsh D (2019) Striving for impartiality: Conflicts of role, trust and emotion in interpreter-assisted police interviews. Pragmat Soc 10(1):122-151. Retrieved June 08, 2019, from https:// www.jbeplatform.com/content/journals/10.1075/ps.00018.wil

Publisher's Note Springer Nature remains neutral with regard to jurisdictional claims in published maps and institutional affiliations. 